\title{
THE
}

1995

\section{Variability in the central equatorial Pacific, 1985-1989}

S. M. Chiswell

Kathleen A. Donohue

University of Rhode Island, kdonohue@uri.edu

Mark Wimbush

University of Rhode Island, mwimbush@uri.edu

Follow this and additional works at: https://digitalcommons.uri.edu/gsofacpubs

Terms of Use

All rights reserved under copyright.

\section{Citation/Publisher Attribution}

Chiswell, S. M., K. A. Donohue, and M. Wimbush (1995), Variability in the central equatorial Pacific, 1985-1989, J. Geophys. Res., 100(C8), 15849-15863, doi: 10.1029/95JC01379.

Available at: https://doi.org/10.1029/95JC01379

This Article is brought to you for free and open access by the Graduate School of Oceanography at DigitalCommons@URI. It has been accepted for inclusion in Graduate School of Oceanography Faculty Publications by an authorized administrator of DigitalCommons@URI. For more information, please contact digitalcommons-group@uri.edu. 


\title{
Variability in the central equatorial Pacific, 1985-1989
}

\author{
S. M. Chiswell ${ }^{1}$ \\ Joint Institute for Marine and Atmospheric Research, University of Hawaii, Honolulu
}

\author{
K. A. Donohue and M. Wimbush \\ Graduate School of Oceanography, University of Rhode Island, Narragansett
}

\begin{abstract}
We describe variability in the equatorial Pacific Ocean near $160^{\circ} \mathrm{W}$ during the 5-year period 1985-1989, encompassing "normal", El Niño, and La Niña conditions. This description is based on conductivity-temperature-depth and acoustic Doppler current profiler data acquired during five cruises between $21^{\circ} \mathrm{N}$ and $4^{\circ} \mathrm{S}$ and on dynamic-height time series from an array based mainly on the Line Islands. At Jarvis Island, near the equator, the time series of dynamic height and near-surface temperature go back to 1981 and show the 1986-1987 El Niño anomalies starting later in the year and having longer duration than those of the 1982-1983 El Niño. Dynamic-height anomaly was less strong for the 1986-1987 event, but the near-surface temperature anomaly was of similar magnitude for the two El Niños. The Jarvis near-surface temperature drop from 1986-1987 El Niño maximum to $1988-1989$ La Niña minimum was $8^{\circ} \mathrm{C}$. Empirical orthogonal function analysis of the time series shows that interannual and interseasonal variability in dynamic height was dominated by a mode with meridional form similar to a first-vertical-mode Kelvin wave, while intraseasonal variability had a primary mode with a single peak at $6^{\circ} \mathrm{N}$ and a secondary mode with peak at $6^{\circ} \mathrm{N}$ and trough at $2^{\circ} \mathrm{N}$. While the equatorial thermocline deepened to the east and shoaled to the west during the $1986-1987 \mathrm{El} \mathrm{Niño}$, at $160^{\circ} \mathrm{W}$ it did not change depth during either this El Niño or the subsequent La Niña. Nevertheless, just before El Niño and just after La Niña, the thermocline was observed to be about $50 \mathrm{~m}$ deeper than at other times. The South Equatorial Current and North Equatorial Countercurrent had markedly reduced (increased) transports during this El Niñ̄o (La Niña). However, the Northern Tsuchiya Jet strengthened during El Niño and weakened during La Niña.
\end{abstract}

\section{Introduction}

Between 1985 and 1989 the equatorial Pacific passed through three phases of the El Niño-Southern Oscillation (ENSO) cycle: a "normal" phase during 19851986, the warm 1986-1987 El Niño, and the cool 19881989 La Niña. Each of these phases lasted about 20 months, and the large-scale evolution of the tropical $\mathrm{Pa}$ cific Ocean and atmosphere during this time has been described by Kousky and Leetmaa [1989] and Delcroix et al. [1992]. McPhaden et al. [1990] and McPhaden and Hayes [1990] (hereinafter referred to as MP1 and MP2, respectively) give accounts of variability during the 1986-1987 El Niño in the western and eastern equa-

\footnotetext{
${ }^{1}$ Now at New Zealand Oceanographic Institute, Wellington, New Zealand.
}

Copyright 1995 by the American Geophysical Union.

Paper number 95JC01379.

0148-0227/95/95JC-01379\$05.00 torial Pacific Ocean, respectively. In the present paper we describe variability in the central equatorial Pacific Ocean between 1985 and 1989, based on once-a-year shipboard measurements of temperature, salinity, and current profiles and on autonomous time series measurements of parameters related to dynamic height.

Subsurface pressure, acoustic travel time, and sea level can all be used to infer dynamic height (see appendix). In February 1985 an array of instruments designed to measure these parameters was deployed along the Line Islands chain in the central Pacific (Figure 1), with the principal aim of investigating variability in dynamic height on timescales from days to years. Subsurface pressure gauges (SSPG) were installed at Palmyra, Fanning, and Malden Islands, augmenting an existing gauge at Jarvis Island. To the north, where there were no islands, this array was extended with inverted echo sounders (IES) deployed at $6^{\circ} \mathrm{N}, 8^{\circ} \mathrm{N}$, and $10^{\circ} \mathrm{N}$. Together with existing sea level gauges (SLG) at Christmas and Penrhyn Islands, the instruments formed an array known as the Line Islands array (LIA), spanning $10^{\circ} \mathrm{N}$ to $9^{\circ} \mathrm{S}$ near $160^{\circ} \mathrm{W}$ (Table 1 ). This array was in place until December 1989. 


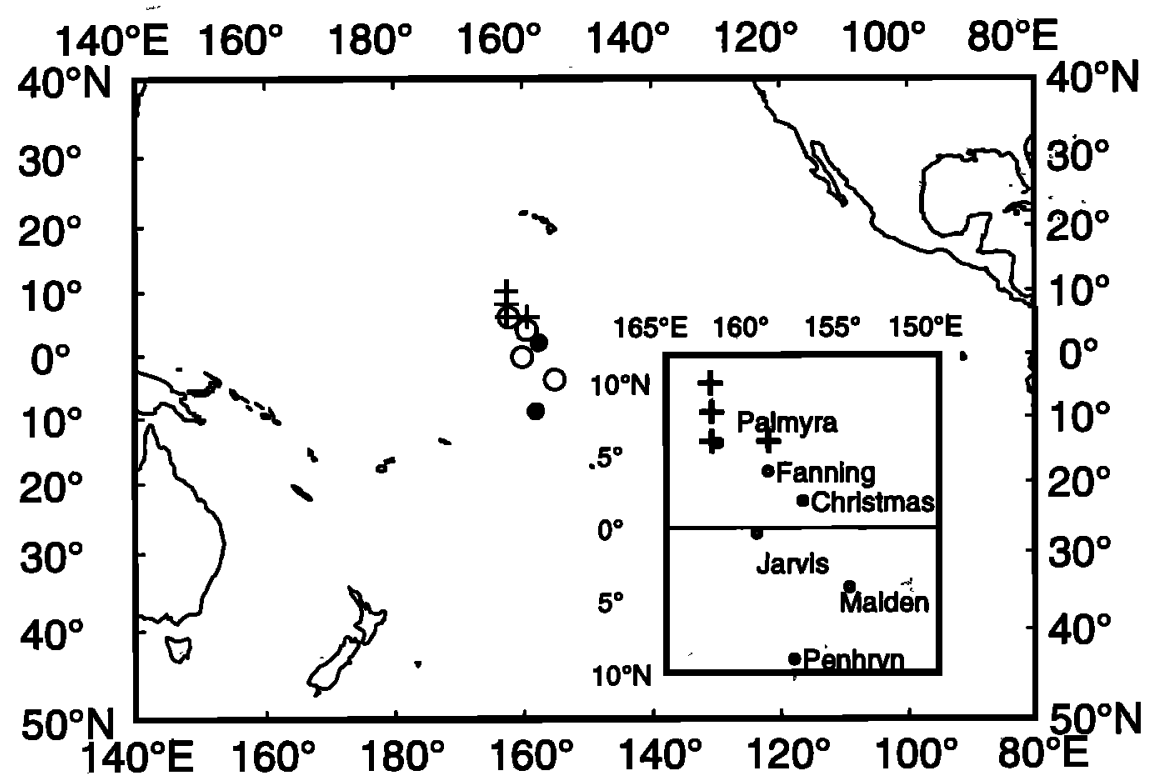

Figure 1. Map of Pacific Ocean showing the location of the Line Islands array. Inverted echo sounders (IESs)(crosses) were deployed at $10^{\circ} \mathrm{N}, 8^{\circ} \mathrm{N}$, and $6^{\circ} \mathrm{N}$ along $162^{\circ} 30^{\prime} \mathrm{W}$ (after 2 years the $6^{\circ} \mathrm{N}$ IES was moved to $159^{\circ} 20^{\prime} \mathrm{W}$ ). Pressure gauges (open circles) were deployed at Palmyra, Fânning, Jarvis and Malden Islands. Tide gauges (solid circles) at Christmas and Penrhyn Islands are part of the Tropical Ocean-Global Atmosphere Pacific sea level network.

The LIA was maintained with a series of cruises to the region at intervals of 1 to 1.5 years. These five cruises (designated LIA 1 to LIA 5) were conducted from Honolulu $\left(21^{\circ} \mathrm{N}\right)$ to Malden Island $\left(4^{\circ} \mathrm{S}\right)$ and return. During each cruise, temperature and salinity sections between Honolulu and Malden Island were made on either the outbound or return leg. The quality of these measurements improved with successive cruises and was best on LIA 4 and 5. On these last two cruises, profiles of horizontal current were also obtained with a hull-mounted acoustic Doppler current profiler (ADCP).

This paper is organized as follows. In section 2 we present the Jarvis Island data (which extend back to 1981 ) and give a brief account of interannual variability from late 1981 until late 1989 . In section 3 we present the LIA time series measurements and describe their relationships to the annual and interannual variability of the background field using empirical orthogonal functions (EOFs). Section 4 discusses our temperature, salinity, and velocity sections from the five cruises and uses them to describe the changing conditions in the central Pacific during 1985-1989. The paper concludes with a short summary and discussion of the main results in section 5 .

In discussing interannual variability, especially with regard to the onset and timing of ENSO signals, it is convenient to refer to some baseline of "normal" or average conditions. Details of the baseline calculation are given in the appendix.

Table 1. Locations and Depths of Line Islands Array Instruments.

\begin{tabular}{llrrr}
\hline Instrument & Island & $\begin{array}{c}\text { Latitude, } \\
\mathrm{N}\end{array}$ & $\begin{array}{c}\text { Longitude, } \\
\text { W }\end{array}$ & $\begin{array}{c}\text { Depth, } \\
\text { m }\end{array}$ \\
\hline IES & & $10^{\circ} 02^{\prime}$ & $162^{\circ} 30^{\prime}$ & 4900 \\
IES & & $8^{\circ} 00^{\prime}$ & $162^{\circ} 27^{\prime}$ & 4400 \\
IES $^{a}$ & & $5^{\circ} 55^{\prime}$ & $162^{\circ} 44^{\prime}$ & 4300 \\
IES $^{b}$ & & $6^{\circ} 00^{\prime}$ & $159^{\circ} 20^{\prime}$ & 4200 \\
SSPG & Palmyra & $5^{\circ} 52^{\prime}$ & $162^{\circ} 06^{\prime}$ & 3.9 \\
SSPG & Fanning & $3^{\circ} 52^{\prime}$ & $159^{\circ} 19^{\prime}$ & 4.5 \\
SLG & Christmas & $1^{\circ} 51^{\prime}$ & $157^{\circ} 28^{\prime}$ & 1.8 \\
SSPG & Jarvis & $0^{\circ} 23_{c}^{\prime}$ & $160^{\circ} 02^{\prime}$ & 5.9 \\
SSPG & Malden & $4^{\circ} 03_{c}^{\prime}$ & $155^{\circ} 00^{\prime}$ & 7.6 \\
SLG & Penrhyn & $9^{\circ} 01_{c}^{\prime}$ & $158^{\circ} 04^{\prime}$ & 1.5 \\
\hline
\end{tabular}

IES is inverted echo sounder, SSPG is subsurface pressure gange, and SLG is sea level gauge.

a Data obtained from February 22, 1985 to June 8, 1987.

${ }^{b}$ Data obtained from June 14, 1987 to December 13, 1989.

c Latitude is south. 


\section{ENSO Cycles 1981-1989}

Subsurface pressure and temperature measured near the equator at Jarvis Island since 1981 can be used to put the 1986-1987 El Niño and 1988-1989 La Niña into a broader context. Figure 2 shows Jarvis Island dynamic-height and temperature anomalies (i.e., with the mean and annual signals removed), along with the Southern Oscillation Index (SOI), from 1981 to 1989.

For the overall 1981-89 period, dynamic height appears to lead near-surface temperature at Jarvis by about 6 months; this is confirmed by a maximum in their cross-correlation function at 5.8 months. Also, Jarvis near-surface temperature and negative SOI appear to be approximately in phase, and this too is confirmed by their cross-correlation function.

After the strong 1982-1983 El Niño [Lukas et al. 1984] the SOI was steady and close to zero until near the middle of 1986, when it began to fall, indicating a weakening of the trade wind system [Kousky and Leetmaa, 1989]. Winds in the western Pacific became anomalously westerly, and there were periods of strong westerly wind bursts in May and November-December 1986. These anomalous westerlies persisted until October 1987, and in response to them there was an increase in Kelvin wave activity across the Pacific Ocean [Delcroix et al., 1991], with one particular pulse in May 1986 well documented [Miller et al., 1988; McPhaden and Taft, 1988]. The oceanic response became evident during 1986, when sea level decreased in the western $\mathrm{Pa}$ cific and increased in the eastern Pacific and widespread warm surface temperature anomalies appeared across the Pacific [MP1; MP2; Reynolds, 1988].

With the onset of El Niño, Jarvis Island dynamic height rose throughout most of 1986 , although several large-amplitude ( 0.1 dynamic meter (dyn. $m$ )) intraseasonal waves (periods 1 to 3 months) occasionally reversed this rise (Figure 2, middle, thin line). Dynamicheight anomaly reached a peak of about 0.28 dyn. $\mathrm{m}$ in December 1986, almost as high as the $1982-1983 \mathrm{El}$ Niño peak, but this was mostly due to one intraseasonal oscillation: when low-pass filtered to remove variability with periods less than 150 days, the 1986-1987 El Niño had a peak amplitude about half that of the 1982-1983 event. The Jarvis Island near-surface tem-
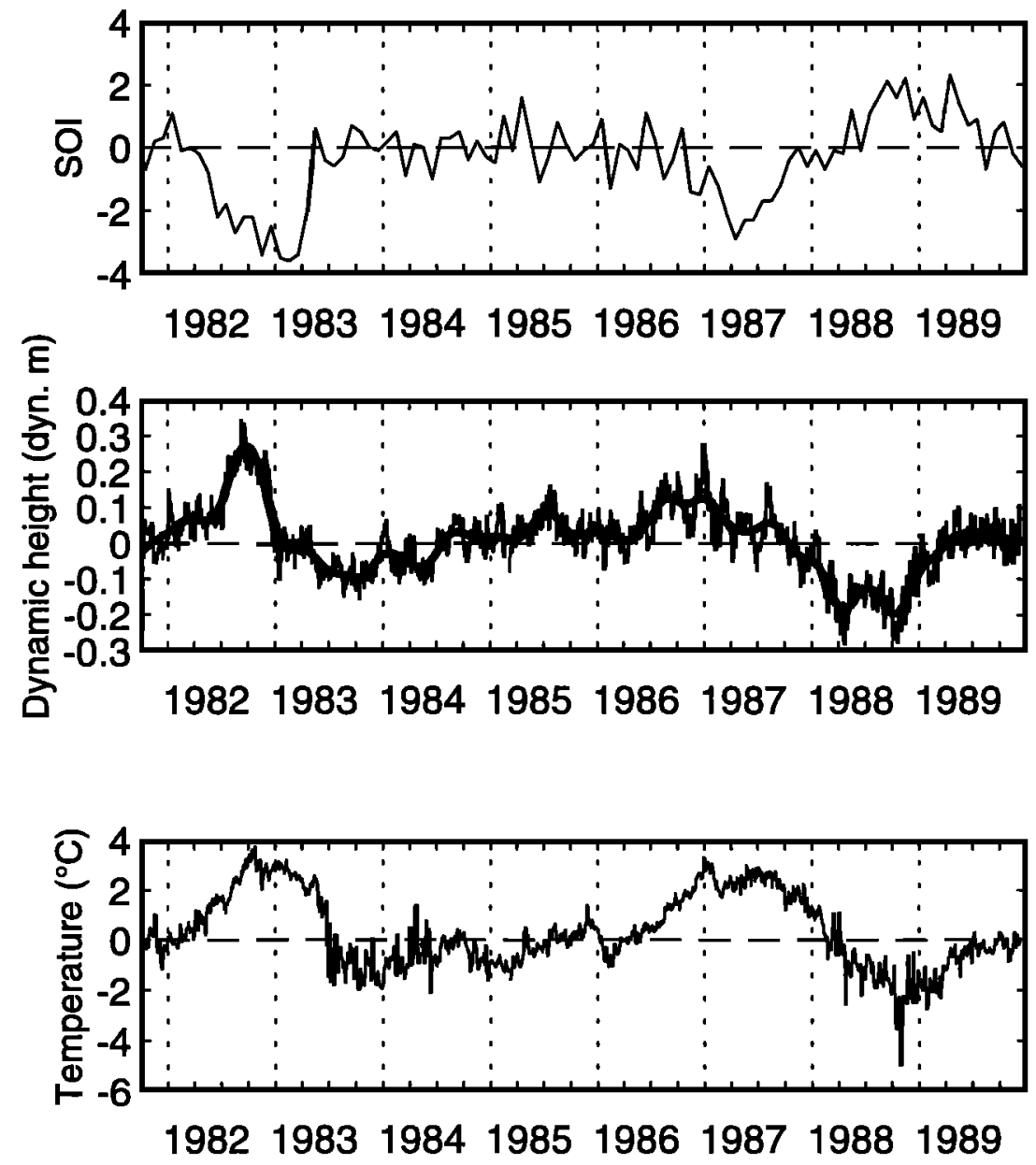

Figure 2. (top) The Southern Oscillation Index (SOI), (middle) Jarvis Island $\left(0^{\circ} 23^{\prime} \mathrm{S}, 160^{\circ} 02^{\prime} \mathrm{W}\right.$ ) dynamic-height and (bottom) near-surface temperature anomalies from 1981 to 1989 . The SOI data are monthly averaged values of Tahiti minus Darwin sea level pressure normalized by the standard deviation. Dynamic height and temperature have means and annual cycles removed. Also plotted is low-pass-filtered dynamic height (cutoff period 150 days). 
perature rise occurred at about the same time as the rise in dynamic height, and the temperature reached $3^{\circ} \mathrm{C}$ above normal in December 1986 , coinciding with the peak in dynamic height. During 1987 both dynamic height and near-surface temperature remained anomalously high (though gradually decreasing).

In April 1987 the SOI reached its lowest value since the 1982-1983 El Niño event and then rose, changing sign from negative to positive early in 1988 after strong easterly trade winds reappeared across the Pacific, initiating La Niña. In September and November of that year the SOI reached values exceeding any in the previous 13 years. The SOI then began to fall, reaching normal values in late 1989 .

During most of 1987, dynamic height and near-surface temperature at Jarvis Island remained anomalously high but gradually decreased in amplitude. This decrease continued into 1988, and by April of that year both of these quantities were anomalously low. Jarvis nearsurface temperature anomaly reached its La Niña minimum in October 1988 , when it was $8^{\circ} \mathrm{C}$ cooler than at its El Niño maximum in December 1986. In 1989 the cold La Niña conditions began to abate, with SOI and Jarvis dynamic-height and near-surface temperature anomalies all returning nearly to zero by the middle of the year.

For the overall 1981-1989 period it appears the ENSOrelated extrema generally occurred first in the Jarvis dynamic-height record, then in the Jarvis temperature record, and last in SOI. The phasing and duration of the 1982-1983 and 1986-1987 El Niño events were different. The dynamic-height rise which developed during the initial year of both El Niños occurred about 3 months later in 1986 than in 1982; also, dynamic height fell rapidly at the end of the initial year in the 19821983 event, while it continued high through most of the subsequent year in the 1986-1987 event. The Jarvis warm anomalies associated with the two El Niños were comparable in strength. In both El Niños the rise in near-surface temperature approximately coincided with that of dynamic height. Near-surface temperature remained high after dynamic height began to fall, and the temperature anomaly did not disappear until about 6 months after dynamic height had returned to normal.

\section{Dynamic Height EOFs}

A consistent dynamic-height data set from the LIA gauges was produced by converting subsurface pressure, acoustic travel time, and sea level to dynamic height. Five major and several minor data gaps caused by loss or failure of the instruments were filled by various means, depending on the site. Figure 3 shows the final data set, with tides and variability at periods of less than about 1 day removed. Details of the data processing, gap filling, and filtering are described in the appendix.

Dynamic height in the Line Islands region is dominated by annual and interannual signals. We have superimposed on each time series the baseline consisting of the annual components computed from all 5 years of each record (excluding the gaps). Except where long gaps affect the calculation of these components, the baselines agree well with dynamic height during 1985 and toward the end of 1989 . From early 1986 until

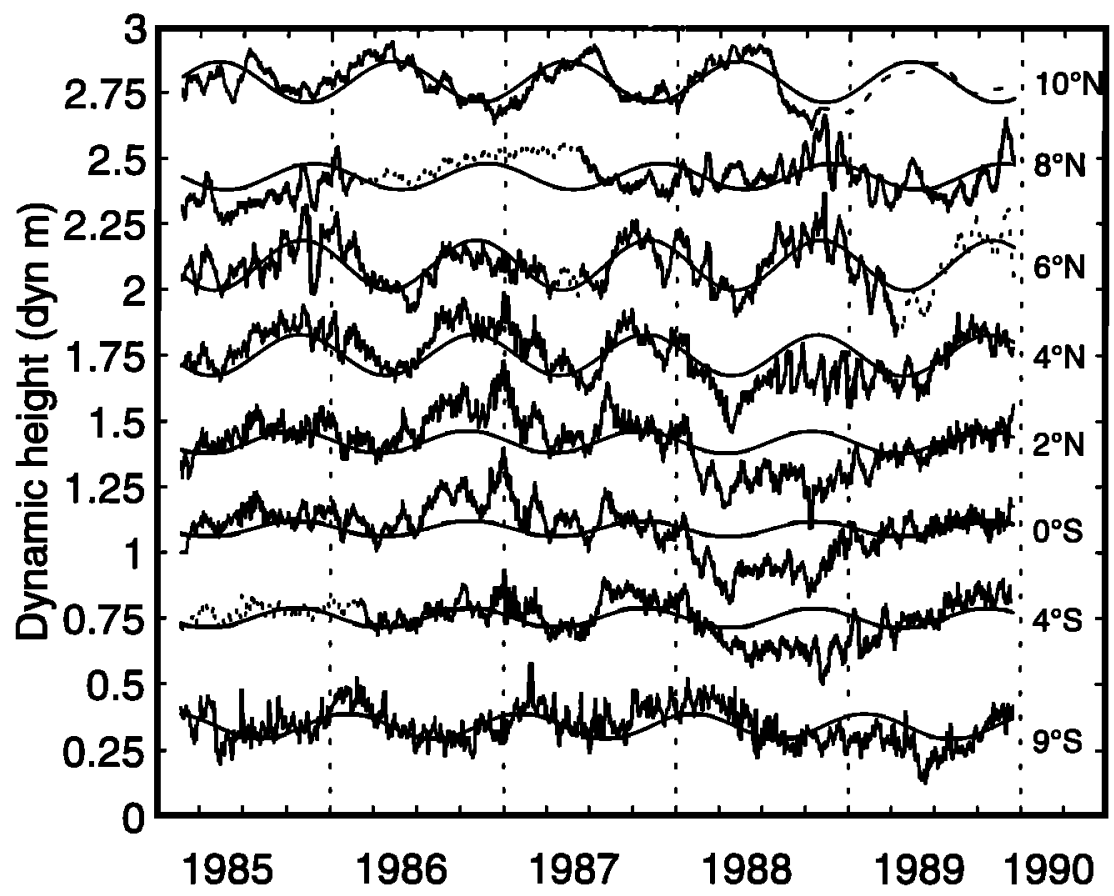

Figure 3. Time series of dynamic height from the Line Islands array. Gaps have been filled as documented by Donohue et al. [1992] and plotted as dots. The dashed line superimposed on each record is its mean annual component. Means have been removed, and the offset between adjacent time series is 0.34 dynamic meters (dyn. $\mathrm{m}$ ). 
early 1989 , however, there were significant departures from the baselines.

EOF analysis was employed to look at the dominant structures of variability, apart from the annual cycle, in the LIA time series of dynamic height. Fluctuations with periods of a few weeks to a few months, having amplitudes comparable to those of the annual and interannual signals, appear in all records in Figure 3. This intraseasonal activity was strongest on the equator and at $6^{\circ} \mathrm{N}$, where occasional waves were larger than the annual cycle (e.g., in late 1985 at $6^{\circ} \mathrm{N}$ ). Autospectra of the dynamic-height records contain a peak near the equator around the 100-day period and another at $6^{\circ} \mathrm{N}$ with 45-day period; these peaks appear to be associated with Kelvin waves and instability waves, respectively [Donohue et al., 1994]. There is no reason to expect that the meridional structures of these two types of waves should be mutually orthogonal. So, prior to EOF analysis, we separated the data into long- and short-period components, whose sum gives the original data, using complementary low- and high-pass, $48 \mathrm{~dB}$-per-octave filters with a cutoff periods of 80 days.

EOFs were computed as the eigenvectors of the covariance matrix after removing the mean and annual signals from each record (i.e., on departures from the baselines shown in Figure 3) and after applying either the low-pass or high-pass filter. We refer to these as "low-pass EOFs" and "high-pass EOFs," respectively. Significance levels were calculated in each case using Monte Carlo simulations using selection rule $\mathrm{N}$ adjusted for data correlation, as suggested by Preisendorfer [1988]. The spatial and temporal components of the resulting significant low-pass and high-pass EOFs are shown in Figures $4 \mathrm{a}$ and $4 \mathrm{~b}$.

Only one low-pass EOF is significant at the $95 \%$ confidence level, accounting for $67 \%$ of the variance. Its spatial structure, resembling a first-vertical-mode equatorial Kelvin wave, is concentrated within about $5^{\circ}$ of the equator. The temporal component of this EOF shows strongest interseasonal ( 3 to 5 months) activity during El Niño (mid-1986 through early 1988). Its interannual variation shows a maximum at the end of 1986 and a minimum in October 1988, similar to dynamic height both at Jarvis (Figure 3) and at $0^{\circ}, 140^{\circ} \mathrm{W}$ (MP2). This EOF suggests, and examination of Figure 3 confirms, that only records from $4^{\circ}$ and closer to the equator show the large interannual signals associated with $\mathrm{El}$ Niño and La Niña. Nevertheless, with only one ENSO cycle of data the confidence of this observation is small.

The two principal high-pass EOFs are significant at the $95 \%$ level. The first is characterized by inphase displacement at all latitudes, with a peak at $6^{\circ} \mathrm{N}$. Its temporal component shows groups of oscillations occurring annually, with maximum amplitude around the end of each year. The oscillations are longest in period ( $\sim 70$ days) and fewest in number during El Niño years. They are shortest in period ( 40 days) and most numerous during La Niña. Contour plots of 1985-1989, $160^{\circ} \mathrm{W}$ dynamic height as a function of time and latitude, based on these LIA data, Geosat data, and out-
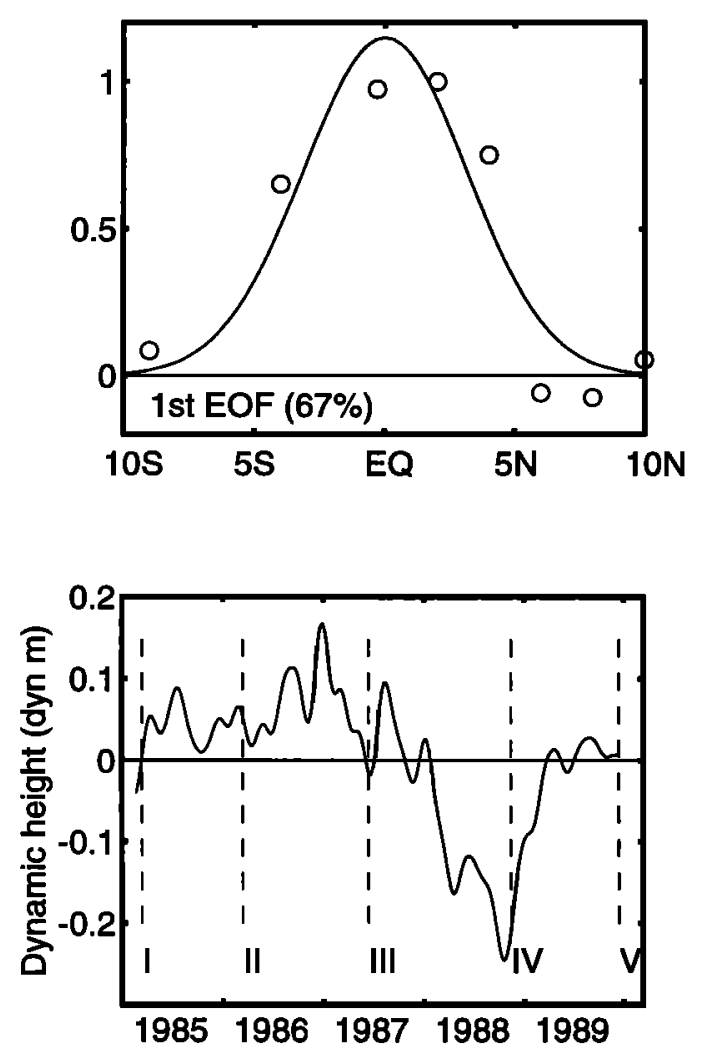

Figure 4a. Spatial (top) and temporal (bottom) first empirical orthogonal function (EOF) components of the 80-day low-passed LIA dynamic-height data. This EOF accounts for the percentage of variance indicated (based on the largest eigenvalue). The line superimposed on the spatial component is the theoretical first-vertical mode Kelvin-wave meridional pressure field structure (assuming $c_{1}=2.8 \mathrm{~m} \mathrm{~s}^{-1}$ ). Dashed lines superimposed on the temporal component show the times of the cruises.

put from a numerical model, all show strongest flow in the South Equatorial Current (SEC) and North Equatorial Countercurrent (NECC), annually in boreal autumn and interannually during La Niña [Donohue et al., 1994]. This EOF is therefore strongest when the currents are strongest. It is probably an equatorial current system instability [Philander et al., 1985].

The second high-pass EOF is characterized by a peak at $2^{\circ} \mathrm{N}$ and an oppositely phased trough at $6^{\circ} \mathrm{N}$. Since the dynamic-height ridge associated with the boundary between the SEC and NECC varies in position between these two latitudes [Donohue et al., 1994], the EOF appears to represent meandering of this current system.

\section{Hydrographic Sections}

Figures $5 \mathrm{a}$ and $5 \mathrm{~b}$ show nearly meridional temperature and salinity sections from the five LIA cruises. In both of these figures we have included a corresponding section reconstructed for June 25 (the midpoint of the LIA 3 section), with the constituents determined by Firing and Lukas [1985] from the Hawaii-to-Tahiti Shuttle Experiment. That experiment [Wyrtki et al., 1981] was conducted slightly to the east at longitudes 

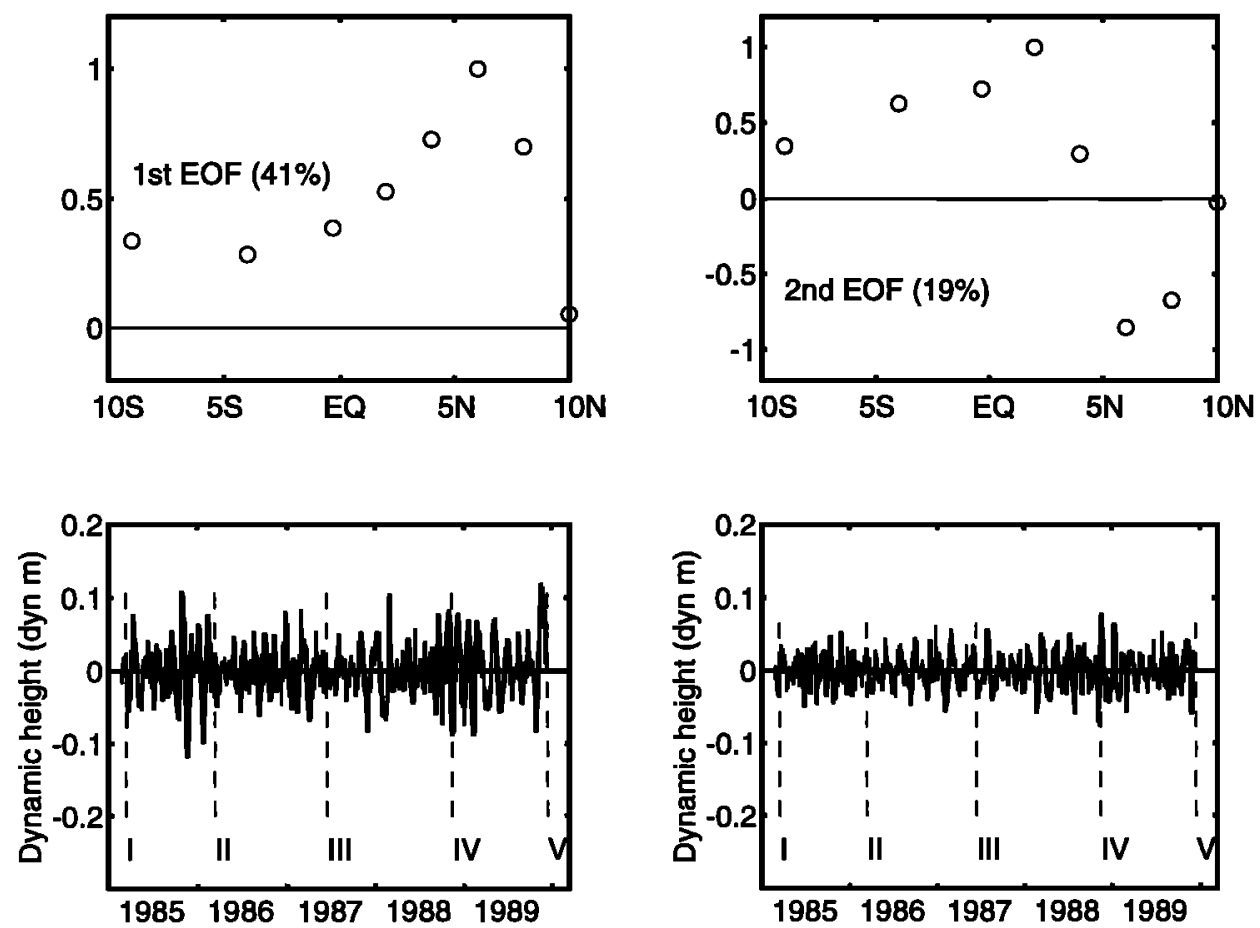

Figure 4b. Spatial and temporal first- and second-EOF components of the 80-day high-passed LIA dynamic-height data. Each EOF accounts for $67 \%$ of variance (based on the corresponding eigenvalue). Dashed lines superimposed on the temporal component show the times of the cruises.

of $150^{\circ} \mathrm{W}, 153^{\circ} \mathrm{W}$, and $158^{\circ} \mathrm{W}$ from February 1979 to June 1980, a period during which there was neither El Niño nor La Niña. Temperature variation in the shuttle data is small compared with that in the LIA sections. For example, equatorial sea surface temperature (SST) varies only a little more than $1^{\circ} \mathrm{C}$ in the shuttle data and $5^{\circ} \mathrm{C}$ in the LIA sections. Thus the June 25 shuttle section may be compared with LIA sections for different times of the year.

\subsection{Temperature (Figure 5a)}

The shuttle temperature section has the classic equatorial form. There is a band of relatively cool surface water centered on the equator. The upper thermocline is shallow at the equator and deepens to the north and south. Within about $2^{\circ}$ of the equator there is a spreading of the isotherms in the thermocline. From about $5^{\circ} \mathrm{N}$ to $9^{\circ} \mathrm{N}$ the thermocline slopes up to the north, rising $55 \mathrm{~m}$. Beyond $9^{\circ} \mathrm{N}$ most isotherms slope gently down to the north. These features of the thermocline are associated through geostrophy, respectively, with the South Equatorial Current (SEC), Equatorial Undercurrent (EUC), North Equatorial Countercurrent (NECC), and North Equatorial Current (NEC) (e.g., for the EUC [Picaut et al., 1989]). Near $4^{\circ} \mathrm{N}$ there is a steep equatorward deepening of the $10^{\circ} \mathrm{C}$ (and neighboring) isotherms, associated with the Northern Tsuchiya Jet (NTJ). The northern edge of the Southern Tsuchiya Jet (STJ) is just visible at the southern limit of the section $\left(4^{\circ} \mathrm{S}\right)$.

Of the five LIA temperature sections the first (March 1985) most closely resembles the shuttle section. Along with the fact that the SOI had shown no sustained de- partures outside the \pm 1 band since mid-1983 (Figure 2), this suggests equatorial Pacific conditions in 1985 best represent normal conditions near $160^{\circ} \mathrm{W}$. Nevertheless, within about $3^{\circ}$ of the equator, surface water is about $2^{\circ} \mathrm{C}$ cooler than the shuttle section, but this is partly because the annual SST cycle here is close to a minimum in March (MP2). Thermocline tilts between the equator and $9^{\circ} \mathrm{N}$ are steeper than in the shuttle section, indicating stronger SEC and NECC.

The March 1986 section shows conditions just prior to onset of El Niño, and the section is similar to that seen a year earlier, although the thermocline, as represented by the depth of the $20^{\circ} \mathrm{C}$ isotherm, is tilted downward everywhere to the south of $8^{\circ} \mathrm{N}$, being about $50 \mathrm{~m}$ deeper at the equator and $70 \mathrm{~m}$ deeper at $4^{\circ} \mathrm{S}$ (the southern limit of these sections) than in March 1985. Deeper isotherms are also affected, with downward displacements of about $50 \mathrm{~m}$ observed at most latitudes south of $13^{\circ} \mathrm{N}$.

The cruise in June 1987 took place 6 months after the local equatorial sea level and SST peaks associated with the 1986-1987 El Niño (Figure 2). Although sea level dropped during these 6 months, SST remained high. In this section the near-equatorial SST minimum has vanished, and SST near the equator is about $4^{\circ} \mathrm{C}$ warmer than in the previous 2 years, exceeding $30^{\circ} \mathrm{C}$ at $2^{\circ} \mathrm{S}$. The classic equatorial thermocline structure has been lost, and isotherms in the thermocline are relatively flat from $4^{\circ} \mathrm{S}$ to $12^{\circ} \mathrm{N}$, indicating weak SEC and NECC (see section 4.3) Reduced thermocline spreading near the equator indicates the EUC core is not well defined. Thermocline depth near the equator is essentially the same as in March 1985. Anomalies related to El Niño 

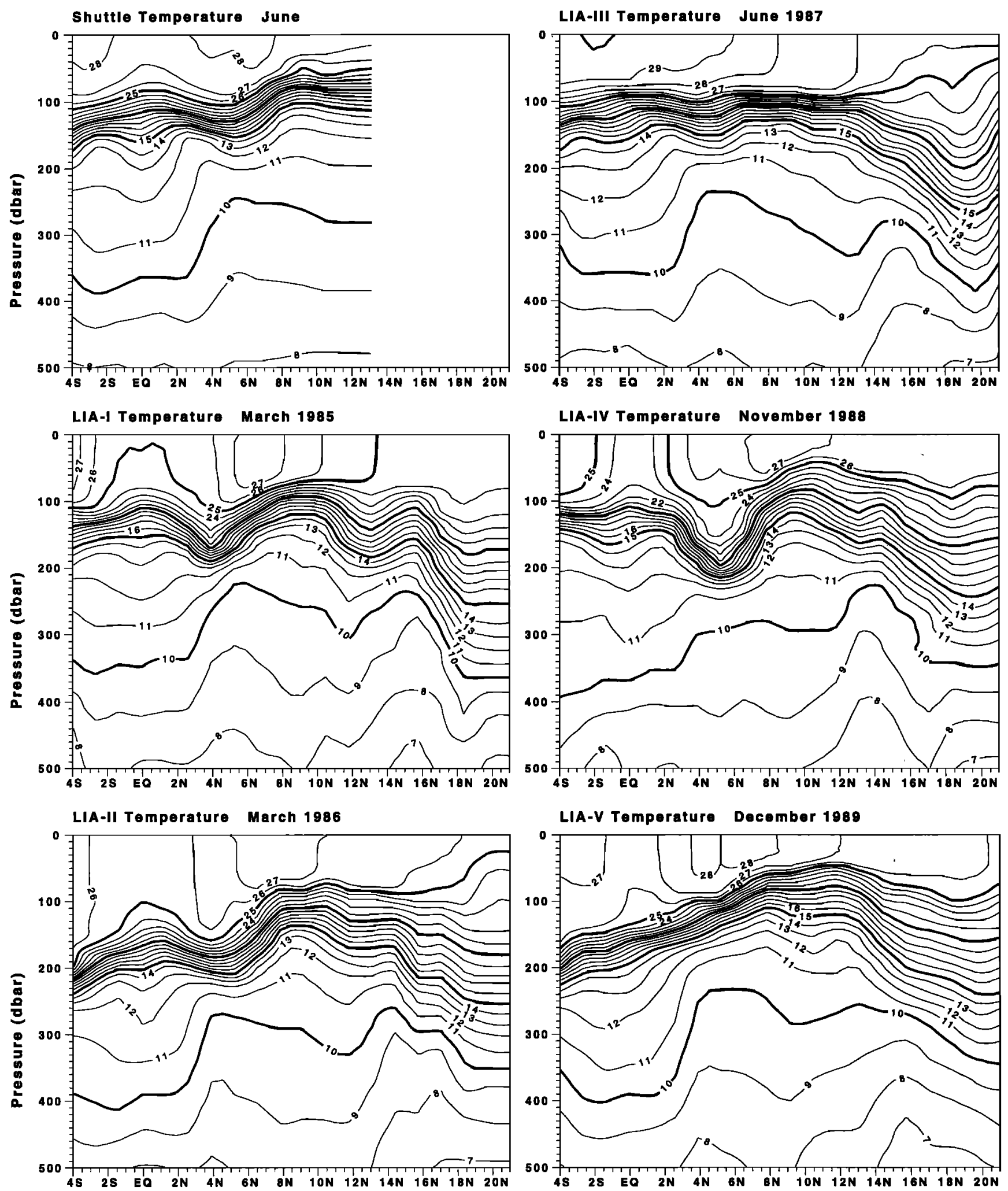

Figure 5a. Temperature sections from the five LIA cruises (LIA 1 to LIA 5). Also included for comparison is the Hawaii-to-Tahiti Shuttle temperature section reconstructed for June 25, using mean, annual, and semiannual components derived by Firing and Lukas [1985].

event appear to be confined to the upper ocean, and for depths greater than $200 \mathrm{~m}$, little difference can be seen between this section and the March 1985 section.

The next cruise took place in November 1988 dur- ing the strongest phase of La Niña, only 1 month after the local anomaly in equatorial sea level reached its nadir (Figure 2). SST near the equator was less than $24^{\circ} \mathrm{C}$. This is $2^{\circ} \mathrm{C}$ cooler than in March 1985 and $6^{\circ} \mathrm{C}$ 

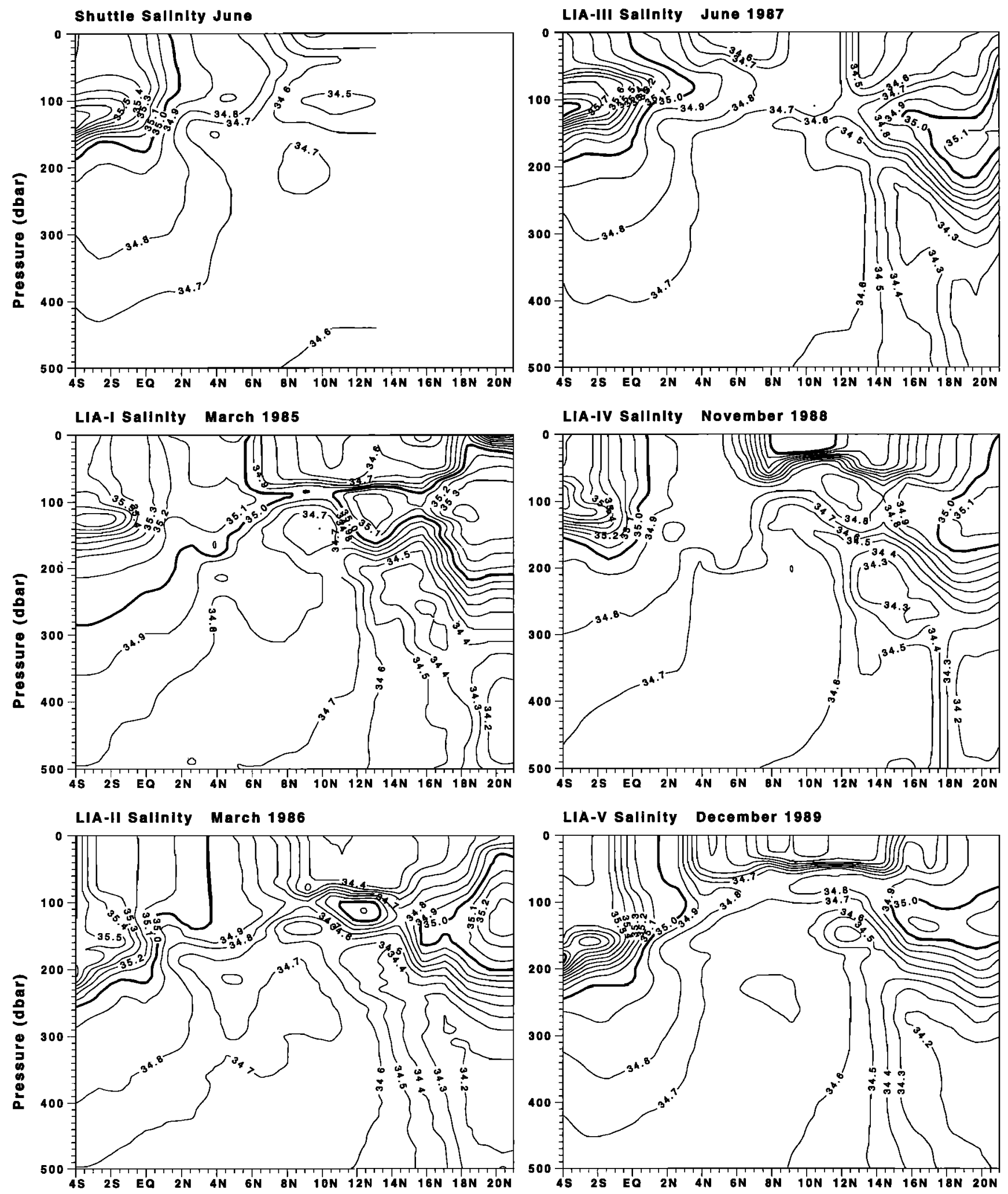

Figure 5b. Same as Figure 5a, but for salinity.

cooler than in June 1987 during El Niño. In the eastern equatorial Pacific, cold SST anomalies at this time were related to large-scale uplift of the thermocline (MP2), but here in the central Pacific, equatorial thermocline depth is nearly the same as in March 1985 . Nevertheless, the cold SST is presumably due to upwelling rather than advection, since current at the equator is eastward (section 4.3). The thermocline has regained its typical equatorial form, but compared with March 1985, isotherm slopes are steeper, implying stronger flows in the SEC, NECC, and EUC, and the trough separating the SEC and NECC has shifted $2^{\circ}$ to the north. As a 

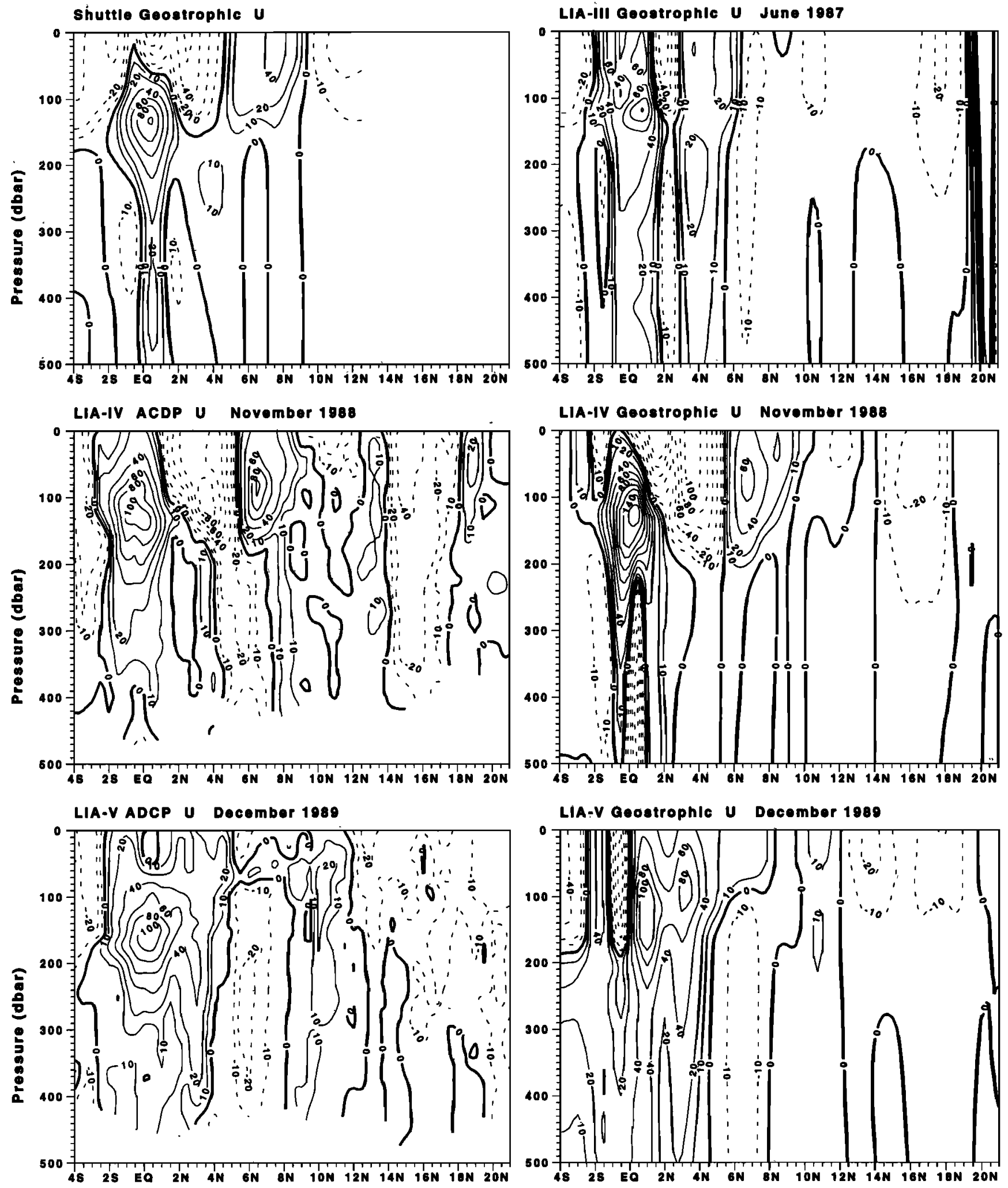

Figure 5c. Geostrophic velocity sections from (top left) the June 25 shuttle section and (right) from the last three LIA cruises (LIA 3 to LIA 5). (middle, bottom left) Zonal velocity measured with the ADCP during LIA 4 and LIA 5.

result of both these features, the thermocline trough is also about $30 \mathrm{~m}$ deeper than it was in March 1985. In contrast to El Niño, La Niña has a pronounced deep temperature signal (compare, for example, the $10^{\circ} \mathrm{C}$ isotherm). Even at depths well below the 250-m base of the thermocline in the trough, isotherms are depressed as much as $100 \mathrm{~m}$ between about $4^{\circ} \mathrm{N}$ and $8^{\circ} \mathrm{N}$. They are similarly depressed at $4^{\circ} \mathrm{S}$. A consequence of this change 
in the deep isotherms is a weakening of the isotherm slopes associated with the Tsuchiya jets and hence of the jets themselves (see section 4.3).

At the time of the final cruise in December 1989, atmospheric conditions in the equatorial Pacific had returned to a nearly normal state. Equatorial SST is within $1^{\circ} \mathrm{C}$ of that in the shuttle section. However, as in March 1986, the thermocline has developed a downward tilt everywhere to the south of $8^{\circ} \mathrm{N}$. This time, there is no thermocline trough, and the thermocline slopes almost linearly downward to the south of $8^{\circ} \mathrm{N}$ all the way to the southern limit of the section at $4^{\circ} \mathrm{S}$. In particular, at the equator the thermocline is $50 \mathrm{~m}$ deeper than during the normal conditions of March 1985.

\subsection{Salinity (Figure $5 b$ )}

The general pattern is one of two high-salinity regions in the upper thermocline and two low-salinity regions, one in the lower thermocline and the other at the surface. One high-salinity region is a tongue from the South Pacific extending just north of the equator; the other is a tongue from the North Pacific extending equatorward to about $15^{\circ} \mathrm{N}$. One low-salinity region is a tongue, below the northern high-salinity tongue, extending upward and equatorward to about $10^{\circ} \mathrm{N}$; the other is a lens of water at the surface centered near $10^{\circ} \mathrm{N}$. These features are all seen in a full meridional section along $160^{\circ} \mathrm{W}$ shown by Reid [1965, Figure 3].

According to Delcroix and Henin [1991], although the dominant water motions are zonal, meridional salinity gradients are so much greater than the zonal gradients that meridional advection has the greater influence on salinity. As a result, the most saline water in the southern high-salinity tongue has its origin in the South Pacific subtropical salinity maximum. It sinks and moves toward the equator. Comparing Figures $5 \mathrm{a}$ and $5 \mathrm{~b}$, we see that the core of this tongue is in the upper thermocline, typically following the $23^{\circ} \mathrm{C}$ isotherm. Consequently, in March 1986 and December 1989, when the thermocline is depressed at the southern end of our section, this high-salinity tongue is also depressed. Similarly, the northern high-salinity tongue originates in the North Pacific subtropical salinity maximum, and like- wise, sinks and moves equatorward. The low-salinity tongue originates in the North Pacific at higher latitudes. It too sinks (because of its cold temperature) and moves equatorward, but at greater depths.

The southern part of the surface lens of low-salinity water is the band of high rainfall associated with the Intertropical Convergence Zone (ITCZ). The northern extension of this lens is due to Ekman transport. The lowest measured salinities in this lens range from 33.9 to 34.4 practical salinity units (psu). This variation is principally a result of the annual rainfall cycle [Delcroix and Henin, 1991]. At the equator, sea surface salinity is greater than 35.1 psu except in June 1987 during El Niño, when it is just under 35.0 psu. This is probably caused by higher-than-usual rainfall in the central equatorial Pacific at this time [Arkin, 1988].

There is often a similar but weaker surface-salinity maximum associated with the South Pacific Convergence Zone [Delcroix and Henin, 1991], but this lies to the south of our sections.

\subsection{Zonal Currents (Figure 5c)}

Geostrophic zonal velocity referenced to 1000 dbar was computed from the LIA and shuttle hydrographic data after averaging the half-degree-spaced dynamicheight field with a five-point Hamming filter to eliminate some aliasing caused by internal tides [Moum et al., 1987]. Currents on the equator were calculated using L'Hôpital's rule [e.g., Lukas and Firing, 1984; Picaut et al., 1989]. Geostrophic sections made during LIA 1 and LIA 2 appear unrealistic (perhaps because of the poorer quality CTD measurements made during those cruises, see appendix) and are not shown here. ADCP measurements of current velocity were made only during LIA 4 and LIA 5. Equatorial current transports estimated from these sections are given in Table 2 (see Table 3 for ranges of these currents). As with temperature, annual variability in geostrophic current in the shuttle is small compared with that in LIA.

Again as with temperature, the shuttle geostrophic section shows classic equatorial structure. The three main surface currents, westward SEC, eastward NECC, and westward NEC, have well-defined strengths, thick-

Table 2. Eastward Current Transports

\begin{tabular}{|c|c|c|c|c|c|c|}
\hline \multirow[t]{2}{*}{ Current } & \multirow{2}{*}{$\begin{array}{r}\text { Shuttle, } \\
\text { June }\end{array}$} & \multirow{2}{*}{$\begin{array}{c}\text { LIA 3, } \\
\text { June } 1987\end{array}$} & \multicolumn{2}{|c|}{ LIA 4, November 1988} & \multicolumn{2}{|c|}{ LIA 5, December 1989} \\
\hline & & & ADCP & 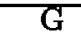 & ADCP & $\mathrm{G}$ \\
\hline SEC & -33 & -14 & -49 & -58 & -13 & -22 \\
\hline NECC & 20 & 13 & 29 & 28 & 9 & 8 \\
\hline NEC & $(-8)$ & -26 & -32 & -22 & -17 & -16 \\
\hline EUC & 30 & (54) & 53 & $(62)$ & 71 & $(112)$ \\
\hline NTJ & 4 & 8 & 2 & 1 & 8 & 13 \\
\hline
\end{tabular}

All values are in Sverdrups $\left(1 \mathrm{~Sv}=10^{6} \mathrm{~m}^{3} \mathrm{~s}^{-1}\right)$

Geostrophic values (G) are given for Hawaii-to-Tahiti Shuttle Experiment and Line Island array 3, 4 and 5. Acoustic Doppler current profiler (ADCP) measured values are given for LIA 4 and LIA 5. Values in parentheses are unreliable because of $13^{\circ} \mathrm{N}$ data limit for shuttle NEC integration and errors in geostrophic calculation near the equator for LIA EUC values (see text).

Abbreviations are LIA, Line Islands array; SEC, South Equatorial Current; NECC, North Equatorial Counter Current; NEC, North Equatorial Current; EUC, Equatorial Undercurrent; and NTJ, Northern Tsuchiya Jet. 
Table 3. Integration Ranges for the Transport Computations used in Table 2.

\begin{tabular}{lcccc}
\hline Current & $\begin{array}{c}\text { Eastward } \\
\text { Current }\end{array}$ & Depth, & \multicolumn{2}{c}{ Latitude Range } \\
& $\mathrm{m}$ & Shuttle, LIA 3 & LIA 4, LIA 5 \\
\hline SEC & $<0$ & $<200$ & $4^{\circ} \mathrm{S}-5^{\circ} \mathrm{N}$ & $4^{\circ} \mathrm{S}-9^{\circ} \mathrm{N}$ \\
NECC & $>0$ & $<200$ & $2^{\circ} \mathrm{N}-16^{\circ} \mathrm{N}$ & $5^{\circ} \mathrm{N}-16^{\circ} \mathrm{N}$ \\
NEC & $<0$ & $<300$ & $>5^{\circ} \mathrm{N}$ & $>9^{\circ} \mathrm{N}$ \\
EUC & $>0$ & $<400$ & $4^{\circ} \mathrm{S}-2^{\circ} \mathrm{N}$ & $4^{\circ} \mathrm{S}-5^{\circ} \mathrm{N}$ \\
NTJ & $>0$ & $200-400$ & $2^{\circ} \mathrm{N}-5^{\circ} \mathrm{N}$ & $2^{\circ} \mathrm{N}-9^{\circ} \mathrm{N}$ \\
\hline
\end{tabular}

These ranges were chosen from Figure 5c.

nesses, and locations. In particular, the NECC occupies the region between $4.5^{\circ} \mathrm{N}$ and $9.5^{\circ} \mathrm{N}$. The eastward subsurface currents are also well defined; the EUC, centered on the equator, extends from $2^{\circ} \mathrm{S}$ to $2^{\circ} \mathrm{N}$, with maximum current speed $100 \mathrm{~cm} \mathrm{~s}^{-1}$ at $130 \mathrm{~m}$, while the NTJ, located at $4^{\circ} \mathrm{N}$, has maximum speed a little over $10 \mathrm{~cm} \mathrm{~s}^{-1}$ at $230 \mathrm{~m}$ depth. Since the STJ core is typically south of $4^{\circ} \mathrm{S}[T$ suchiya, 1975], only the edge of it appears in this section. Unlike all the LIA sections, the shuttle section shows the SEC as a current whose westward flow is unbroken at the surface, albeit with a pronounced velocity minimum due to EUC influence at $0.5^{\circ} \mathrm{S}$.

The shuttle section shows well-defined geostrophic currents [Lukas and Firing, 1984] because the influence of internal tides and nonsynoptic sampling has been strongly suppressed through averaging. This is not the case for our sections, and we expect that geostrophic calculations of velocity will become especially unreliable close to the equator (Coriolis $f \rightarrow 0$ ). Comparing the ADCP and geostrophic velocity sections for 1988 and 1989 , we do indeed see large discrepancies within about $3^{\circ}$ of the equator. It appears individual hydrographic sections cannot be used reliably to infer currents at latitudes below $3^{\circ}$.

In June 1987, during El Niño, the ADCP was not yet available, and we have only the geostrophic velocity section. It shows an EUC extending upward to the surface. Although within the equatorial band, where geostrophic calculations become unreliable, this feature may be correct, since it is also seen in the 1988 and 1989 ADCP sections. If we take it as correct, the EUC separates the SEC into two branches: a branch to the south of $2^{\circ} \mathrm{S}$ and a narrow northern branch centered on $2^{\circ} \mathrm{N}$. With this reduced meridional extent the SEC transport is less than half that in the shuttle section. The NECC also has reduced meridional extent, lying between $3^{\circ} \mathrm{N}$ and $6.5^{\circ} \mathrm{N}$ (Figure 5c). Having a width of $3.5^{\circ}$ and measured maximum speed of $29 \mathrm{~cm} \mathrm{~s}^{-1}$, compared with shuttle values of $5^{\circ}$ and $49 \mathrm{~cm} \mathrm{~s}^{-1}$, the NECC transport in June 1987 is only two thirds that in the shuttle section. In contrast, we obtain a transport of $54 \mathrm{~Sv}$ for the EUC, compared with $30 \mathrm{~Sv}$ for the June shuttle section, but because of the uncertainties in the geostrophic method near the equator, we cannot say whether the EUC transport is anomalous in June 1987. (Comparison of the ADCP and geostrophic estimates of the EUC for LIA 4 and LIA 5 suggests the geostrophic calculation grossly overestimates the transport). The EUC had normal strength at this time both at $110^{\circ} \mathrm{W}(\mathrm{MP} 2)$ and at $165^{\circ} \mathrm{E}$ (MP1), though at the latter location it weakened and reversed during the next 4 months in response to local westerly wind anomalies in June and July. The June 1987 section shows the NTJ at its usual position, but with double the speed and transport shown in the shuttle section.

The November 1988 velocity sections, taken during La Niña conditions, show strong, deep SEC and NECC flows, with transports about $50 \%$ greater than in the shuttle section. The ADCP and geostrophic sections both show that the SEC again appears split into two branches by an EUC which reaches the surface. Both the SEC and NECC have $(\sim 100 \mathrm{~m})$ velocity maxima in excess of $60 \mathrm{~cm} \mathrm{~s}^{-1}$. The boundary between these two currents is at $5^{\circ} \mathrm{N}$. The ADCP section (which, near the equator, is the more reliable section) shows an EUC having structure similar to that in the shuttle experiment, except that it breaks the surface between $2.5^{\circ} \mathrm{S}$ and $1^{\circ} \mathrm{N}$ and carries about $75 \%$ more transport. The NTJ is weak.

Because the surface flow near the equator is eastward and equatorial SST is warmer to the west [Delcroix et al., 1992], the cold SST anomaly along the equator is not the result of zonal advection. Easterly winds at Christmas Island were stronger than normal during 1988 (MP2), and cool equatorial SST is presumably the result of increased upwelling.

For December 1989 the geostrophic and ADCP sections are similar only for latitudes farther than about $2^{\circ}$ from the equator; near the equator they differ substantially. For this reason, we base the following discussion on the ADCP section. The EUC again appears to reach the surface, but the region of eastward flow is now especially large; it extends from about $2^{\circ} \mathrm{S}$ to $5^{\circ} \mathrm{N}$ (except for a small piece near the surface between $0^{\circ}$ and $1^{\circ} \mathrm{N}$ ), and its core is deep $(130 \mathrm{~m})$. Moreover, the EUC carries a large transport (71 Sv). The northern branch of the SEC is very weak near the surface. The NECC is even weaker than in June 1987 but is located about $5^{\circ}$ farther north. The NTJ is strong and is located at $3.5^{\circ} \mathrm{N}$, about a half-degree closer to the equator than previously. Computed current transports at this time appear more like those during El Niño than those at other times. This is perhaps a response to the western Pacific westerly wind bursts which began in late November 1989 [McPhaden et al., 1992]. 


\section{Summary and Discussion}

During the period 1985-1989 we observed conditions, approximately along $160^{\circ} \mathrm{W}$, in two types of measurements: infrequent (approximately once a year) vertical profiles of temperature, salinity, and current and frequent (approximately once an hour) measurements of dynamic height. EOF analyses of the dynamic-height time series showed variability at periods greater than 80 days was dominated by a mode whose meridional form peaked at the equator and resembled the theoretical first-vertical-mode Kelvin wave. This mode had strong interannual and interseasonal oscillations. Its interseasonal oscillations were strongest during El Niño. At periods less than $\mathbf{8 0}$ days there were two significant modes: a principal mode with a single peak at $6^{\circ} \mathrm{N}$ and a secondary mode associated with meandering of the SEC/NECC dynamic-height ridge. These two modes were strongest around the end of the year and during $\mathrm{La}$ Niña. Those are the times when currents are strongest, and it is probable that both modes represent oscillations of the ridge by tropical instability waves.

The temperature section obtained on the cruise in March 1985 was similar to that of a composite from the Hawaii-to-Tahiti Shuttle data. Taken together with the fact that neither SOI nor dynamic height over the array was anomalous during 1985 (Figures 2 and 3 ), this suggests conditions throughout 1985 can be regarded as normal for the region.

The following features were observed near the equator. In the central Pacific Ocean the 1986-1987 El Niño first became evident when dynamic-height and nearsurface temperature anomalies began to rise in mid1986. Just before this, in March 1986 the thermocline was depressed $50 \mathrm{~m}$ (relative to the shuttle section); this may have been associated with heat buildup on the western side of the Pacific prior to El Niño. Dynamic height and near-surface temperature rose rapidly with the onset of El Niño and reached highest values by the end of 1986 before dropping at different rates. In June 1987, 6 months after the peak of the event, dynamic height had fallen to about half its maximum value, although near-surface temperature still remained close to its highest value. By this time the thermocline had returned to about the same depth as in the March 1985 and shuttle sections (but was relatively flat from $4^{\circ} \mathrm{S}$ to $12^{\circ} \mathrm{N}$ ). The sections indicate the dynamic-height signal (Figure 2) was principally due to warming of the upper waters rather than deepening of the thermocline. During this El Niño, according to MP1 and MP2, the thermocline deepened to the west (at $165^{\circ} \mathrm{E}$ ) and shoaled to the east (at $110^{\circ} \mathrm{W}$ and, to a lesser extent, $140^{\circ} \mathrm{W}$ ). It appears the longitude of $160^{\circ} \mathrm{W}$ was, as it were, the pivot point for the seesawing equatorial thermocline. In June 1987, increased rainfall during El Niño resulted in lower surface salinity; also, SST was $4^{\circ} \mathrm{C}$ warmer than in March 1985 and lacked an equatorial minimum. The transition from the 1986-1987 El Niño to the 1988-1989 La Niña occurred quickly; by March 1988, dynamic height was almost 0.2 dyn. $m$ below the mean. Dy- namic height and near-surface temperature remained anomalously low throughout 1988 . The 1988-1989 La Niña lasted for over a year in the central Pacific; dynamic height returned close to mean levels in the first half of 1989, and near-surface temperature and SOI did likewise in the second half. In contrast to the normal depth of the thermocline in November 1988, the thermocline depth in November 1989 was depressed (as in March 1986); this may have been associated with heat buildup prior to the stalled 1990 El Niño [Angell, 1992].

Reliable velocity sections were obtained only during the last 3 years. In all velocity sections the EUC reached the surface, separating the SEC into two branches, but uncertainties introduced by geostrophic calculation near the equator prevented reliable determination of EUC transport in June 1987. Current transports during El Niño and La Niña were considerably different from those computed from the shuttle data. In June 1987, 6 months after peak El Niño conditions, the SEC transport was reduced by nearly $60 \%$ and the NECC by $35 \%$ from shuttle values. In November 1988, near the peak in La Niña, SEC and NECC transports were both almost $50 \%$ larger than shuttle values. NTJ transport was affected oppositely, being larger by a factor of 2 during El Niño and smaller by a factor of 2 during La Niña. In December 1989, shortly after the end of La Niña, there was a large region of eastward flow encompassing the EUC; also the thermocline trough, which is usually found near $4.5^{\circ} \mathrm{N}$ was absent and, consequently, the NECC was weak. However, in the next paragraph we present evidence that this absence of the thermocline trough was a brief occurrence which would have lasted only a week or two.

To what extent are the differences between our hydrographic sections representative of interannual signals? Our low-pass EOF, which predominantly describes the interannual ENSO signal, is limited to the region within about $5^{\circ}$ of the equator. Yet, in the hydrographic sections we see significant changes in thermocline depth extending to $8^{\circ} \mathrm{N}$ (section 4.1). At $140^{\circ} \mathrm{W}$, M. J. McPhaden (personal communication, 1994) saw isotherm displacements as large as $50 \mathrm{~m}$ associated with intraseasonal waves. Could intraseasonal waves be responsible for such features as the disappearance of the thermocline trough near $5^{\circ} \mathrm{N}$ in our December $1989 \mathrm{sec}-$ tion (Figure 5a)? The cospectra of lagged LIA time series indicate a wavelength of $1400 \mathrm{~km}$ and a westward phase propagation for these waves [Donohue et al., 1994]. Thus the CTD section (through $5^{\circ} \mathrm{N}, 156^{\circ} 20^{\prime} \mathrm{W}$ ) was about a quarter of a wavelength away from the LIA array (Table 1) in the direction from which the waves were propagating. During the time CTD casts were taken near $5^{\circ} \mathrm{N}$ the principal high-pass EOF (Figure $4 \mathrm{~b}$, bottom left) passed through zero, going from high to low dynamic height. Putting these facts together, it appears dynamic height due to intraseasonal waves at the CTD section would have been close to a minimum at the time the CTD casts were taken. Moreover, the meridional structure of the waves (Figure $4 \mathrm{~b}$, top left) resembles that of the mean dynamic-height 
ridge [Donohue et al., 1994, Figure 2), and their amplitudes are also similar, $O(0.1$ dyn. $\mathrm{m})$. Consequently, at the time and place of the CTD measurements in 1989 we would expect rough mutual cancellation of dynamic height from the mean-field ridge and from the intraseasonal waves. This is apparently the reason the usual $5^{\circ} \mathrm{N}$ thermocline trough, which is responsible for the dynamic-height ridge, does not appear in the December 1989 CTD section (Figure 5a).

\section{Appendix: Data Processing}

\section{Dynamic-Height Time Series}

The Paroscientific Digiquartz pressure sensors used in the Sea Data SSPGs during the first two deployments (from February 1985 until June 1987) suffered from production defects that resulted in gradual drifts of up 0.4 dbar in their output signals. During the last year's record (November 1988 to December 1989) the $4^{\circ} \mathrm{S}$ gauge again showed an apparent drift. Fortunately, there were enough other measurements (in situ and satellite) to allow us to show with confidence that the drifts were linear. Details of these drift removals are given by Chiswell and Lukas [1989]. Subsurface pressure was converted to dynamic-height units by dividing it by 1.022 (decibars per dynamic meter), representing mean near-surface density over the entire array.

Acoustic travel time data from the IESs were converted to dynamic height using the results of Chiswell et al. [1988] and Wimbush et al. [1990], which compared the subsurface pressure at Palmyra Island $\left(6^{\circ} \mathrm{N}\right)$ with acoustic travel time from the nearby IES to show that travel time $\tau$ was linearly related to dynamic height $\delta D$ in this region by $\delta D=\left(-70\right.$ dyn. $\left.\mathrm{m} \mathrm{s}^{-1}\right) \tau$. Details of the IES processing are given by Fields et al. [1991] and Donohue et al. [1992].

SLG data were provided by the Tropical Ocean-Global Atmosphere Sea Level Center [Wyrtki, 1979]. Details of the data processing are given by Kilonsky and Caldwell [1991]. Sea level was multiplied by 0.98 (gravity/10) to convert it to dynamic height.

\section{Gap Filling}

The dynamic-height data set contains seven minor ( $<2$ weeks) data gaps, mostly associated with instrument changeovers, and five major ( $>8$ weeks) gaps resulting from instrument loss or failure. The first year from $4^{\circ} \mathrm{S}$, the second year from $8^{\circ} \mathrm{N}$, and the last year from $10^{\circ} \mathrm{N}$ are missing because the instruments were lost. In addition, there are two gaps of a few months each at Palmyra Island due to failure of the pressure gauge. Since there was only 1 year in which we had data from all sites, these gaps were filled appropriately to obtain a data set which could be analyzed in a uniform manner (Figure 3). Details of the gap filling are given by Donohue et al. [1992]. In particular, three gaps of $\sim 1$ year each at $4^{\circ} \mathrm{S}(1985-1986), 8^{\circ} \mathrm{N}(1986-1987)$, and $10^{\circ} \mathrm{N}(1988-1989)$ were filled as follows. Multiple linear regression was used to fit the $9^{\circ} \mathrm{S}$ and $0.4^{\circ} \mathrm{S}$ data to the available $4^{\circ} \mathrm{S}$ data, and the required patch at $4^{\circ} \mathrm{S}$ was formed using those coefficients. Similarly, the $6^{\circ} \mathrm{N}$ and $10^{\circ} \mathrm{N}$ data were fitted to the available $8^{\circ} \mathrm{N}$ data, and the required patch at $8^{\circ} \mathrm{N}$ was formed. Because no data were available north of $10^{\circ} \mathrm{N}$, the patch there was formed by summing the extensions of $0.5,1,2$, and 3 cpy sinusoids, which had been fitted (in amplitude and phase) to the preceding $10^{\circ} \mathrm{N}$ data.

The major deep and shallow water tides, including the fortnightly $\mathbf{M}_{f}$ tide, were removed from the records. The time series were then low-pass filtered using a Gaussian filter having -3-db attenuation at 24-hour periods and subsampled at 12-hour intervals.

\section{Near-surface Temperature}

The pressure gauge at Jarvis Island also recorded temperature. The gauge was installed at a depth of $6 \mathrm{~m}$ on the reef encircling the island and should accurately represent open ocean conditions.

\section{CTD Profiling}

All cruises began and ended in Honolulu. On every cruise, CTD casts were made at each IES site and near each island instrumented with a pressure gauge. Sections were also made with casts at every degree of latitude (every half degree between $3^{\circ} \mathrm{N}$ and $3^{\circ} \mathrm{S}$ ) on a direct course between Malden and Honolulu, typically taking 10 days. On the March 1985, March 1986, and June 1987 cruises, sections were made on both the outgoing and returning legs of the cruise; on the November 1988 and December 1989 cruises a complete section was made only on the leg in which a direct course was steered between Malden and Hawaii.

The quality of these measurements improved with successive cruises and was best on LIA 4 and 5. On LIA 1, 2, and 3 internally recording CTDs were used, Applied Microsystems STD-12 on LIA 1 and 2, and Sea-Bird SBE-09 on LIA 3. Water samples for conductivity calibrations were collected with Niskin bottles. On LIA 4, and 5 the Sea-Bird SBE-09 CTD was used with shipboard recording of the data and a 12-place rosette for water sampling.

\section{ADCP Profiling}

Shipboard ADCP measurements were made continuously during the final two cruises using the RD Instruments VM-150 profiler installed on the R/V Moana Wave. The signal-processing bin length was $8 \mathrm{~m}$ in the vertical. ADCP and navigation data processing methods are described in detail by Bahr et al. [1990].

\section{Baseline Definition}

Historical data from the central equatorial Pacific are limited, but the Hawaii-to-Tahiti shuttle Experiment [Wyrtki and Kilonsky, 1984] from January 1979 until June 1980 was conducted in years without either pronounced La Niña or El Niño conditions and therefore provides one description of normal conditions. Firing and Lukas [1985] computed mean, annual, and semiannual constituents of the temperature, salinity and 
dynamic-height fields from the shuttle data. For island locations south of $4^{\circ} \mathrm{N}$ there is little difference between the Firing and Lukas constituents of surface dynamic height and corresponding ones computed from our 5 years of LIA data. However, north of $4^{\circ} \mathrm{N}$, agreement between the shuttle and LIA components gets progressively worse. At $10^{\circ} \mathrm{N}$ there is almost no agreement, even though there was little interannual variability in the $10^{\circ} \mathrm{N}$ dynamic height during LIA. For this reason, we define our baseline of dynamic height to be the reconstruction of the mean and annual components computed for each LIA site. Nevertheless, our hydrographic sections can be compared with a reconstruction made from the Firing and Lukas constituents.

Acknowledgments. We acknowledge the help of many people who participated in the Line Islands array project. Special thanks are due to Roger Lukas, who conceived and executed much of the original Line Islands program, including the deployment of the pressure gauges and organizing the cruises. He also reviewed this article and gave us helpful advice on it. Eric Firing kindly supplied the ADCP data, and Klaus Wyrtki the tide gauge data from Christmas and Penrhyn Islands. Gerry Chaplin and Mike Mulroney prepared, deployed and recovered the IESs. Ken Constantine and Jefrey Snyder were instrumental in many aspects of the field work. The efforts of the captains and crews of R/V Moana Wave, S/V Machias, and R/V Kila were essential to the success of the cruises. We thank Sharon Decarlo, Eric Loucks, Lance Fujieki, Janice Sato, Bo Yang, and Kenny Chu for help in processing the pressure gauge and CTD data. Julie Ranada processed and analyzed the ADCP data. Ted Walsh performed the salinity analyses. We appreciate the care with which the anonymous reviewers read our manuscripts, and especially the many useful suggestions provided by one of the reviewers. This work was supported by the National Science Foundation under grants OCE-8408640, OCE-8917495, and by the U.S. TOGA project office of NOAA through contract NA85AA-D-AC092. The New Zealand Oceanographic Institute generously provided sabbatical support to one of the authors (M.W.) during the time this paper was written.

\section{References}

Angell, J.K., Evidence of a relation between $\mathrm{El} \mathrm{Niño} \mathrm{and}$ QBO for an El Niño in 1991-92, Geophys. Res. Lett., 19, 285-288, 1992.

Arkin, P.A., The global climate for June-August 1987: Mature phase of an ENSO warm episode persists, J. Clim., 1, 306-324, 1988.

Bahr, F., E. Firing, and S. Jiang, Acoustic doppler current profiling in the western Pacific during the US-PRC TOGA cruises 5 and 6, Data Rep. 7, Joint Inst. for Mar. and Atmos. Res., Univ. of Hawaii, Honolulu, 1990.

Chiswell, S.M., and R. Lukas, The low-frequency drift of Paroscientific pressure transducers, J. Atmos. Oceanic Technol., 6, 389-395, 1989.

Chiswell, S.M., M. Wimbush, and R. Lukas, Comparison of dynamic height measurements from an inverted echo sounder and an island tide gauge in the central Pacific, $J$. Geophys. Res., 93, 2277-2283, 1988.

Delcroix, T., and C. Henin, Seasonal and interannual variations of sea surface salinity in the tropical Pacific Ocean, J. Geophys. Res., 96, 22 135-22 150, 1991.

Delcroix, T., J. Picaut, and G. Eldin, Equatorial Kelvin and Rossby waves evidenced in the Pacific Ocean through
Geosat sea level and surface current anomalies, J. Geophys. Res., 96, 3249-3262, 1991.

Delcroix, T., G. Eldin, M. Radenac, J. Toole, and E. Firing, Variation of the western equatorial Pacific Ocean, 19861988, J. Geophys. Res., 97, 5423-5445, 1992.

Donohue, K.A., M. Wimbush, S. Chiswell, and R. Lukas, Line Islands array 1985-1989 data report: Dynamic height time series, GSO Tech. Rep. 92-5, Grad. School of Oceanogr., Univ. of R.I., Narragansett, 1992.

Donohue, K.A., M. Wimbush, X. Zhu, S.M. Chiswell, R. Lukas, L. Miller, and H.E. Hurlburt, Five years' central Pacific sea level from in situ array, satellite altimeter, and numerical model, Atmos.-Ocean, \$2, 495-506, 1994.

Fields, E., K. Tracey, and D.R. Watts, Inverted echo sounder data processing report, Tech. Rep. 91-3, Grad. School of Oceanogr., Univ. of R.I., Narragansett.

Firing, E., and R. Lukas, Sampling and aliasing during the NORPAX Hawaii-to-Tahiti shuttle experiment, J. Geophys. Res., 90, 11 709-11 718, 1985.

Kilonsky, B., and P. Caldwell, In pursuit of high quality sea level data, paper presented at Oceans '91, IEEE MTS Conference, Inst. Electr. and Electr. Eng., New York, 1991.

Kousky, V. E., and A. Leetmaa, The 1986-1987 Pacific warm episode: Evolution of oceanic and atmospheric anomaly fields, J. Clim., 2, 254-267, 1989.

Lukas, R., and E. Firing, The geostrophic balance of the Pacific equatorial undercurrent, Deep Sea Res. Part A, 31, 61-66, 1984.

Lukas, R., S.P. Hayes, and K. Wyrtki, Equatorial sea level response during the 1982-1983 El Niño, J. Geophys. Res., $89,10425-10430,1984$.

McPhaden, M.J., and S.P. Hayes, Variability in the eastern equatorial Pacific Ocean during 1986-1988, J. Geophys. Res., 95, 13 195-13 208 and 13 573-13 577, 1990.

McPhaden, M.J., and B.A. Taft, On the dynamics of seasonal and intraseasonal variability in the eastern equatorial Pacific, J. Phys. Oceanogr., 18, 1713-1732, 1988.

McPhaden, M.J., S.P. Hayes, L.J. Mangum, and J.M. Toole, Variability in the western equatorial Pacific during the 1986-1987 El Niño/Southern Oscillation event, J. Phys. Oceanogr., 20, 190-208, 1990.

McPhaden, M.J., F. Bahr, Y. du Penhoat, E. Firing, S.P. Hayes, P.P. Niiler, P.L. Richardson, and J.M. Toole, The response of the western equatorial Pacific Ocean to westerly wind bursts during November 1989 to $1990, J$. Geophys. Res., 97, 14 289-14 303, 1992.

Miller, L., R.E. Cheney, and B.C. Douglas, GEOSAT altimeter observations of Kelvin waves and the 1986-1987 El Niño, Science, 239, 52-54, 1988.

Moum, J.N., T.K. Chereskin, M.M. Park, and L.A. Regier, Monitoring geostrophic currents at the equator, Deep Sea Res. Part A, 34, 1149-1161, 1987.

Philander, S.G.H., D. Halpern, D. Hansen, R. Legeckis, L. Miller, C. Paul, R. Watts, R. Weisberg, and M. Wimbush, Long waves in the equatorial Pacific Ocean, EOS Trans. $A G U ., 66,154,1985$.

Picaut, J., S.P. Hayes, and M.J. McPhaden, Use of the geostrophic approximation to estimate time-varying zonal currents at the equator, J. Geophys. Res., 94, 3228-3236, 1989.

Preisendorfer, R.W., Principal Component Analysis in Meteorology and Oceanography, edited by C.D. Mobley, 425 pp., Elsevier, New York, 1988.

Reid, J.L., Intermediate waters of the Pacific Ocean, Johns Hopkins Oceanogr. Stud., 2, 85 pp., 1965.

Reynolds, R.W., A real-time global sea surface temperature analysis, J. Clim., 1, 75-86, 1988.

Tsuchiya, M., Subsurface countercurrents in the eastern equatorial Pacific Ocean, J. Mar. Res 39, supp., 145-175, 1975. 
Wimbush, M., S.M. Chiswell, R. Lukas, and K.A. Donohue, Inverted echo sounder measurement of dynamic height through an ENSO cycle in the central equatorial Pacific, IEEE J. Oceanic Eng., 15, 380-383, 1990.

Wyrtki, K., Sea level variations: Monitoring the breath of the Pacific, EOS Trans. AGU., 60, 25-27, 1979.

Wyrtki, K., and B. Kilonsky, Mean water and current structure during the Hawaii-to-Tahiti Shuttle Experiment, $J$. Phys. Oceanogr., 14, 242-254, 1984.

Wyrtki, K., E. Firing, D. Halpern, R. Knox, G.J. McNally, W.C. Patzert, E.D. Stroup, B.A. Taft, and R. Williams, The Hawaii-to-Tahiti Shuttle Experiment, Science, 211, 22-28, 1981.
S. M. Chiswell, New Zealand Oceanographic Institute, P.O. Box 14-901, Kilbirnie, Wellington, New Zealand. (email: chiswell@storm.greta.cri.nz)

K. A. Donohue and M. Wimbush, Graduate School of Oceanography, University of Rhode Island, Narragansett, RI 02882. (email: kathyd@ono.gso.uri.edu; markw@ono.gso.uri.edu)

(Received May 20, 1993; revised March 21, 1995; accepted May 2, 1995.) 